\title{
Quality Function Deployment (QFD) on Product Design Development: Group Riding Safety Equipment
}

\author{
Muhammad Ridwan Andi Purnomo ${ }^{\# *}$, Rizqi Ramadhani ${ }^{\#}$, Afif Asbani ${ }^{\#}$, Ahmad Rizal Yassaruddin", \\ Bella Azis Dewanti Putri", Arman Adhi Dharmawan ${ }^{\#}$ \\ ${ }^{\#}$ Industrial Engineering Department, Universitas Islam Indonesia, Jl.Kaliurang KM 14.5, Yogyakarta, 55581, Indonesia \\ e-mail:"ridwan_ie@uii.ac.id
}

\begin{abstract}
Motorcycle communities have a variety of activities, a common one is group's touring or taking a long journey for several purposes such charity as well for community's gathering. Some condition found in this kind of situation, groups touring creates situations which make whole pack member have to be a focus on their groups riding. In the group's touring, it is widespread for them to using body gestures in order to communicate in a pack. They create some signals by using their body parts which commonly by hand or feet, to deliver their messages such: accelerate; turning; notifying obstacles; break; etc. This contradiction found precarious and dangerous, improper driving position as well with losing focus on driving will endanger the touring group and its surrounding. Considering the existed contradiction, researchers are trying to formulate the solution. GONDEZ "Going on Road Safely" The Touring Safety Riding Equipment with Integrated Control System. The innovation uses to alternate the contradictive condition; the device helps the rider in delivering the messages without creating improper dangerous driving gestures. The research methodology adopted from KAIZEN philosophy, followed by QFD as the methods in order to identify and designing the product.
\end{abstract}

Keywords - KAIZEN; QFD; integrated; safety; groups; riding; GONDEZ.

\section{INTRODUCTION}

The number of motor vehicles in Indonesia until 2013 reached 104,211 million units of which 86.253 million units were motorcycles [2]. High social culture in Indonesia encourages people with similarities to form specific communities. Until now, the growing community of motorcycle lovers of the current developments that produce many types of motor vehicles. The data in JABODETABEK area indicates there is 70 touring motor community that officially formed. Not to mention the addition of the number of touring motor community that has not been officially registered. While for Yogyakarta there are two motorcycle communities.

Accurate motorcyclist mileage estimates are important because self-evaluation of riding experience is related to riding behavior [3]. The mileage is divided into several classifications. The estimated time is usually taken for 1 to 2 hours with a distance below 100 kilometers. Short Touring with an estimated time is usually 3-4 hours with a distance above 100 kilometers. Medium Touring with Estimated Time Usually 7-8 hours or half day with a distance above 250 kilometers. The last is Long Touring/Long Journey with an estimated time is usually 11-12 hours sometimes with a distance of more than $500 \mathrm{~km}$.
In practice, it is widespread for them to using body gestures in order to communicate in a pack. They create some signals by using their body parts which commonly by hand or feet, to deliver their messages such: accelerate; turning; notifying obstacles; and break. The body gesture conducted so that group leaders can provide information to individual community members who will be forwarded in chains. It is considered quite dangerous because of the distance traveled and the time to be pursued, awkward driving position as well with losing focus on driving will endanger the touring group and its surrounding. In the event of an accident or an emergency, anyone must stop the motorcycle as quickly as possible; any vehicle can hurt your motorcycle from the back if they cannot stop the vehicle. However, when driving in groups it will be difficult to avoid a consecutive crash [10].

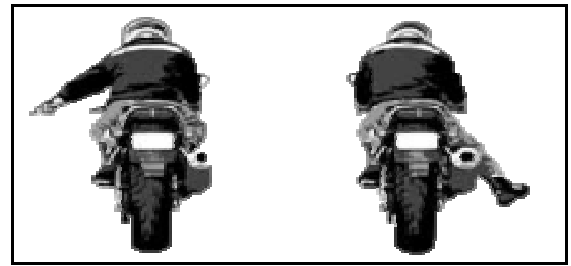

Fig. 1 Motorcyclist Body Gestures Illustration (source: Motorcycle Operator Manual $16^{\text {th }}$ Edition) 
It will be inflicting a single-vehicle accident, or multiple accidents will be the worst scenario. Mr. Taufik G. a police officer from POLRESTA Yogyakarta who in charge on traffic control division gave a statement, using the body gestures to communicating while driving that forcing the rider to use one hand or one foot in driving their vehicle is an illegal and might be very dangerous while driving in the high speed. Crashes at higher speeds may result in multiple injuries likely to cause death [12]. Looking at the existing problem, the researcher has developed a supporting device which entitled: GONDEZ "Going on Road Safely," Safety Tool Riding with Integrated Control System. This innovative device creates several signs or symbols which will be displayed on every riders' back who interconnected to each other, where the group leader performs the control system. Each rider will be able to receive signals as well as to forward the signal. This possibly is more effective in avoiding the potential accidents which come from the unpropped driving gesture, while giving more integrated and effective communication among the riders.

\section{MATERIAL AND METHOD}

In conducting this research, we focused on solving problems which found on the object of our observation. Developing an innovative device in order to offer a solution to solving the problem is on our framework. As for the research process, we adopted the KAIZEN (Plan-Do-CheckAction) philosophy and used Quality Function Deployment or commonly known as QFD to analyze the problem. This is because conceptually, QFD can be used in mapping the problems of an object and resolved using existing tools. The implementation of KAIZEN philosophy is expected can give a continuous improvement. Thus, in conducting the research, we can evaluate the process not only regarding product development but also the whole process that involved.
Lantech Inc has proved the effectiveness of KAIZEN implementation on the process of product development. By applying kaizen to both the product design and production planning phases, they dramatically telescoped their new product development cycle with the following results [9],

- In the past two years, they have completely revamped their product offerings: today. More than 80 percent of the sales come from products two years old or younger.

- In the past year, they have developed and introduced three Important new product lines.

- In the past nine months, they have taken a new product from concept to production - a process that, before kaizen, might have required as much as four years!

The research proposed driving safety tool by combining audio, haptic and visual. In their research, the use of audio is quite effective, but the weakness is, it requires very simple languages to communicate with among riders. The use of haptic also feels effective but requires a more in-depth tool development, whereas in the visual aspect the researcher only puts a strip light on the rear-view mirror so that it is less visible to the rider who is behind it [11].

\section{A. Problem Identification}

Constructing a proper research sometimes also begins with the fidelity of identifying the problem. Without problem formulation, the researcher will lose direction in doing their research. As a researcher, we observed some irregularities that we can found in our surrounding. The identified problem of this study found on common local traffic phenomenon existed in Indonesia. As explained in the introductory of this study, most motorcycle riders whose riding in a group create a potential threat for them which can lead to a dangerous traffic accident. This problem has get proven as severe problem by TMC POLDA Metro Yogyakarta (Traffic Management Centre).

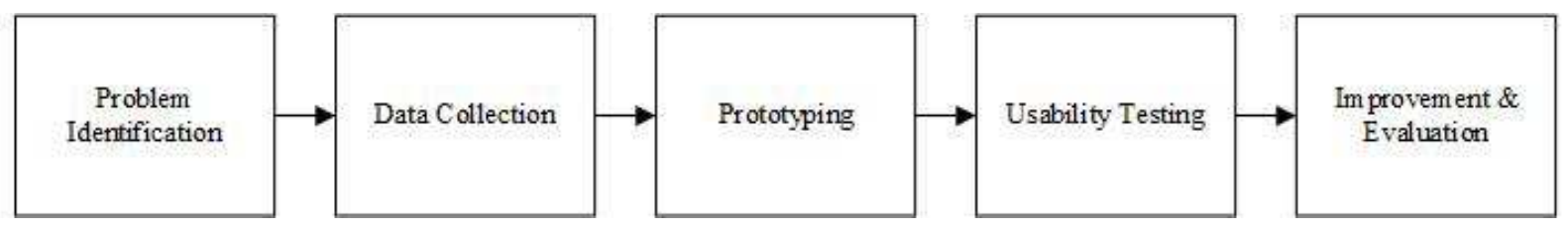

Fig. 2 Research Process

This condition also supported by the shortlisted of Group Riding Ethics that motorcyclist must considered [8],

- Base the length of the route and segments on ability of the least experienced rider.

- Take timely breaks to prevent loss of concentration and reduce fatigue.

- Adjust the pace through curves to the ability of the least experienced rider. If necessary, form two groups with different speeds.

- Don't tailgate or encourage the rider in front to speed. If you want to ride faster, ride ahead of the group.

- Keep adequate following distance and maintain a staggered formation.

- Do not pass in the group, except in the case of emergency.
- Place inexperienced riders just behind the leader so they can keep pace without riding faster than it is safe.

- When passing, be conscious of the traffic conditions and oncoming traffic. Even though the previous riders passed safely, it may not be safe for you.

- Maintain adequate time distance between riders, especially at intersections. This allows you to avoid hard braking.

- Check your mirrors frequently to ensure the group stays together.

\section{B. Data Collection}

Data collection framework of this study is following the phases of QFD Methods. Knowing that the development of QFD is divided into 4 phases, the collection of the data conducted at phase 1 . 
TABLE I

Data Collection Result FOR IDENTIFying PERFoRMAnCe FACTOR

\begin{tabular}{|c|l|l|}
\hline $\begin{array}{c}\text { Degree of } \\
\text { Conformity }\end{array}$ & \multicolumn{1}{|c|}{$\begin{array}{c}\text { Performance Factor } \\
\left(1^{\text {st }} \text { Distribution }\right)\end{array}$} & \multicolumn{1}{|c|}{$\begin{array}{c}\text { Performance } \\
\text { Factor } \\
\left(2^{\text {nd }} \text { Distribution }\right)\end{array}$} \\
\hline 1 & - & - \\
\hline 2 & Color Contrast & - \\
\hline 3 & Simplicity of Design & Reflectiveness \\
\hline 4 & $\begin{array}{l}\text { Stylish, Bright Display, } \\
\text { Energy Compatibility, } \\
\text { Windproof, Blinking }\end{array}$ & $\begin{array}{l}\text { Bright display, } \\
\text { Blinking display }\end{array}$ \\
\hline
\end{tabular}

\begin{tabular}{|c|c|c|}
\hline & $\begin{array}{l}\text { Display, Reflective } \\
\text { Display, Wide Coverage }\end{array}$ & \\
\hline 5 & $\begin{array}{l}\text { Adaptive, Reminder, } \\
\text { Safety, Comfort, Easy to } \\
\text { use, Simple Design, } \\
\text { Waterproof, Durable, Clear } \\
\text { symbol, Dustproof, Light, } \\
\text { Affordable }\end{array}$ & $\begin{array}{l}\text { Stylish, Simple, } \\
\text { Color contrasts, } \\
\text { Reminder, Safety, } \\
\text { Comfort, Easy to } \\
\text { use, Clear symbol, } \\
\text { Wide coverage, } \\
\text { Windproof, } \\
\text { Waterproof, } \\
\text { Durable, Affordable }\end{array}$ \\
\hline
\end{tabular}

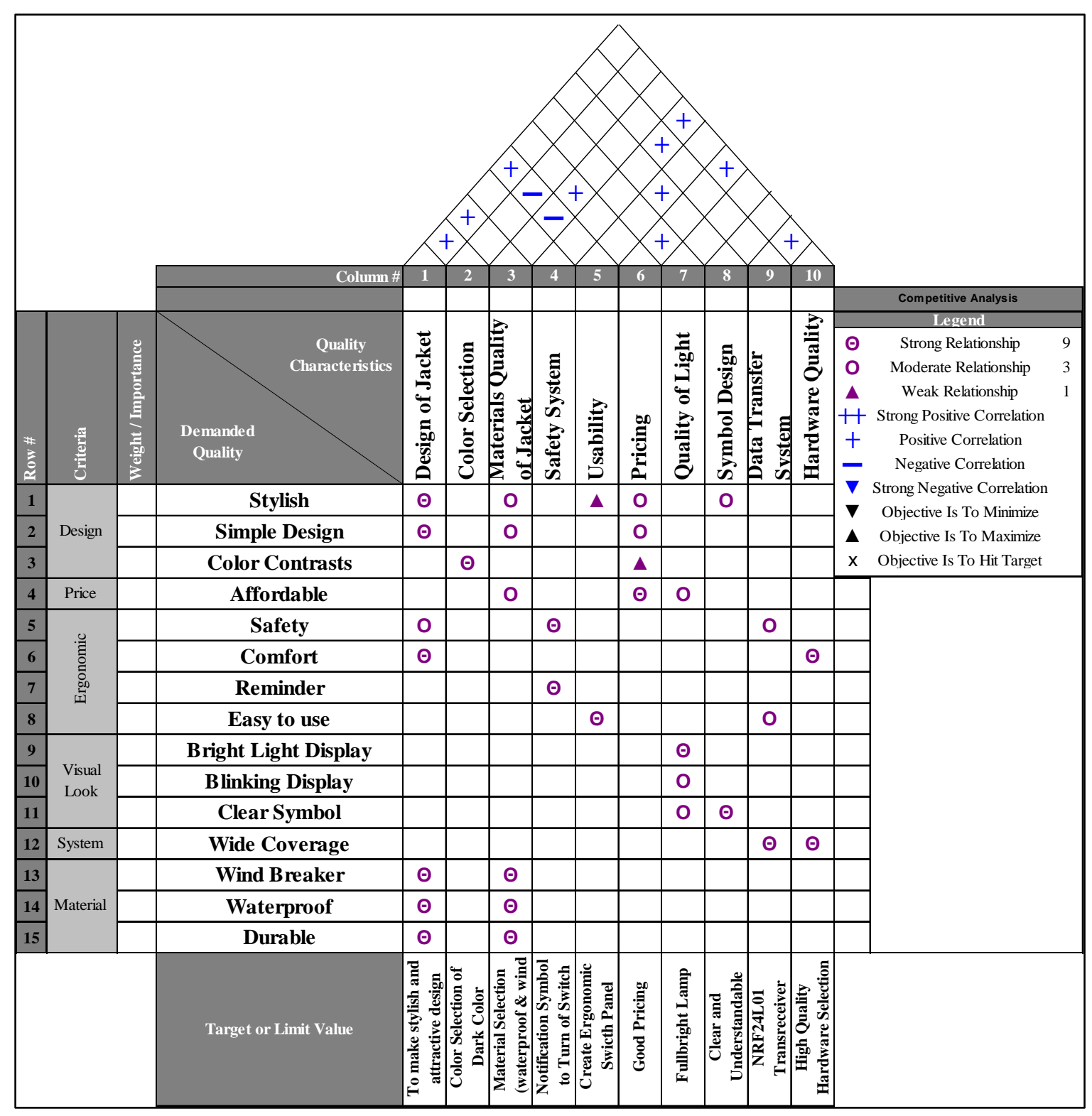

Fig. 3 HOQ 1 Diagram 


\begin{tabular}{|c|c|c|c|c|c|c|c|c|c|c|c|c|c|c|}
\hline & Column \# & $\neq 1$ & 2 & 3 & 4 & 5 & 6 & 7 & 8 & 9 & 10 & 11 & 12 & 13 \\
\hline & $\mathrm{HOQ} 2$ & \multirow{2}{*}{ 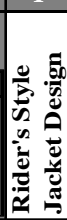 } & \multirow{2}{*}{ 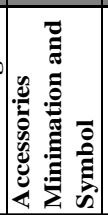 } & \multirow[b]{2}{*}{$\begin{array}{l}\frac{\dot{0}}{0} \\
\dot{u} \\
\dot{\pi}\end{array}$} & \multirow{2}{*}{ 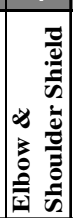 } & \multirow{2}{*}{ 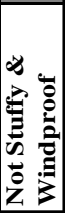 } & \multirow[b]{2}{*}{ 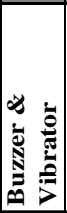 } & \multirow{2}{*}{ 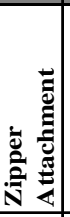 } & \multirow{2}{*}{ 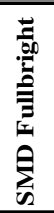 } & \multirow{2}{*}{ 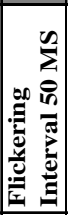 } & \multirow{2}{*}{ 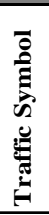 } & \multirow[b]{2}{*}{ 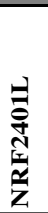 } & \multirow{2}{*}{ 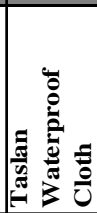 } & \multirow[b]{2}{*}{$\overline{\mathbf{Z}}$} \\
\hline & \begin{tabular}{ccc||}
$\boldsymbol{O}$ & Strong Relationship & 9 \\
$\mathbf{O}$ & Moderate Relationship & 3 \\
$\mathbf{\Delta}$ & Weak Relationship & 1 \\
\end{tabular} & & & & & & & & & & & & & \\
\hline 1 & Maculine Design & $\Theta$ & & $\Theta$ & 0 & $\Delta$ & & 0 & & & $\Delta$ & & 0 & 0 \\
\hline 2 & Not Full of Accessories & & $\Theta$ & & O & & $\Delta$ & 0 & $\Delta$ & & & & $\Delta$ & \\
\hline 3 & Neutral Color & & & $\Theta$ & & & & & & & & & $\Theta$ & 0 \\
\hline 4 & Shield Addition & 0 & $\Delta$ & & $\Theta$ & & & $\Delta$ & & & & & 0 & $\Theta$ \\
\hline 5 & Adaptive & 0 & & & & $\Theta$ & & & & & & & & \\
\hline 6 & Create Focus & & & & & & $\Theta$ & & & & & & & \\
\hline 7 & Lock Types & & & & & & & $\Theta$ & & O & 0 & & & \\
\hline 8 & Contrasts & & & 0 & & & & & $\Theta$ & & 0 & & $\Delta$ & $\Theta$ \\
\hline 9 & Light Display Adjustment & & & & & & & & 0 & $\Theta$ & 0 & & & \\
\hline 10 & Informative Symbol Design & & & & & & & & $\Theta$ & 0 & $\Theta$ & & & \\
\hline 11 & Transreciever & & & & & & & & & & & $\Theta$ & & \\
\hline 12 & Layers Material & & & & & & & & & & & & $\Theta$ & \\
\hline 13 & Good Quality Material & $\Theta$ & & & & & & & $\Theta$ & & & & $\Theta$ & $\Theta$ \\
\hline
\end{tabular}

Fig. 4 HOQ 2 Diagram

A consideration has put on this process. As a researcher of this study, we limit our process of QFD development only up to the second phase. This decision comes from this study's objective, which focuses only on designing the product. As a result, the collected data can be seen in Table I.

\section{Prototyping}

After several processes on planning phase been conducted, the resulted data gave visualization for prototyping the product. There are some types of prototyping, in this study, we develop the product to reach the alpha stage of prototyping. Which is implementing the system integration, furthermore after conducting usability test the product will be upgraded to beta prototype [7].

\section{Usability Test}

To examine the product, usability testing done to a specific user which are the bikers whose ever or annually riding in a group. The objective of conducting a usability test is to assure the customer expectation towards the product and to get direct feedback for evaluating and improving the prototype while specifying the respondents expects to result in more objective and directed feedback.

\section{E. Improvement}

Based on the usability test responds, evaluation and improvement done towards the prototype. Several actions would be taken to get ideal benchmarking of the product. More advanced prototyping would be taken to come up to the final product.

\section{RESULTS AND DISCUSSION}

This research began by distributing an online questionnaire to find out the voice of the customer. A total of 40 respondents, stated 22 desired criteria in safety factor for group riding jacket. The criteria are then re-asked to the respondents to find out what they want through the validity and reliability test. The results of validity testing on Table II shows all the data is valid and $\mathrm{R}$ Table $(\mathrm{N}-2)$ values are 0,3044 with Ho is rejected.

TABLE II

VALIDITY TEST RESUlT WITH 5\% SigNIFICANCE (0.05)

\begin{tabular}{|c|c|c|}
\hline No & Criteria & $\begin{array}{c}\text { Pearson } \\
\text { Correlation }\end{array}$ \\
\hline $\mathbf{1}$ & Stylish & 0.424 \\
\hline $\mathbf{2}$ & Simple Design & 0.620 \\
\hline $\mathbf{3}$ & Color Contrasts & 0.603 \\
\hline $\mathbf{4}$ & Reminder & 0.416 \\
\hline $\mathbf{5}$ & Safety & 0.424 \\
\hline $\mathbf{6}$ & Comfort & 0.331 \\
\hline $\mathbf{7}$ & Easy to use & 0.593 \\
\hline $\mathbf{8}$ & Bright display & 0.443 \\
\hline $\mathbf{9}$ & Not reflective & 0.413 \\
\hline $\mathbf{1 0}$ & Flickering & 0.583 \\
\hline $\mathbf{1 1}$ & Simple symbol & 0.704 \\
\hline $\mathbf{1 2}$ & Wide coverage & 0.840 \\
\hline $\mathbf{1 3}$ & Wind Breaker & 0.598 \\
\hline $\mathbf{1 4}$ & Waterproof & 0.619 \\
\hline $\mathbf{1 5}$ & Durable & 0.632 \\
\hline
\end{tabular}




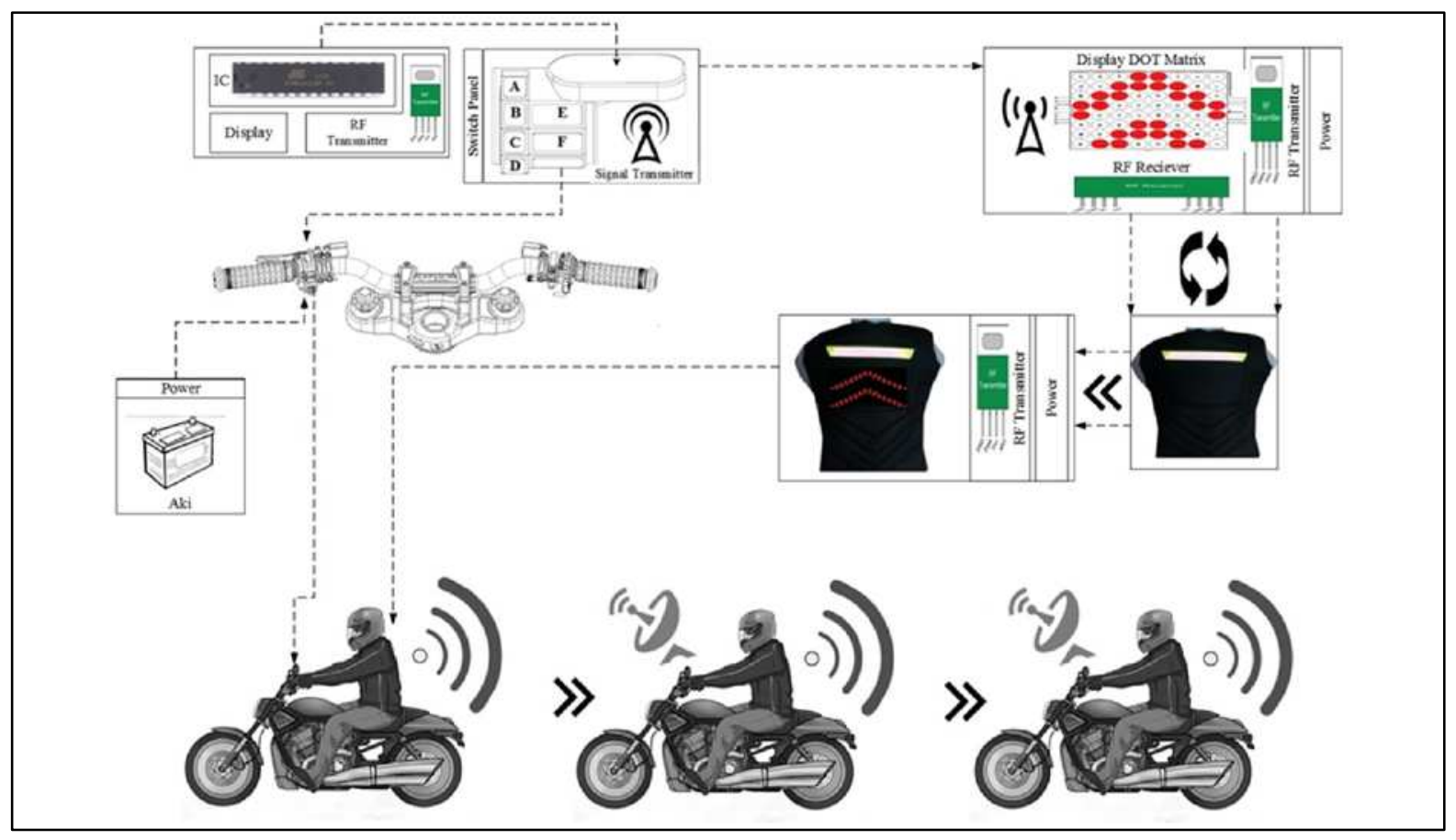

Fig. 5 Device Operation System

TABLE III

RELIABILITY TEST RESULT

\begin{tabular}{|c|c|c|}
\hline $\begin{array}{c}\text { Cronbach's } \\
\text { Alpha }\end{array}$ & $\begin{array}{c}\text { Based on Standardized } \\
\text { Items }\end{array}$ & N of Items \\
\hline .873 & .885 & 22 \\
\hline
\end{tabular}

Furthermore, the reliability test shows that the result is reliable as shown in Table III. Based on the result of the validity and reliability test, 15 criteria become the voice of customer needs.

The 15 criteria then adopted to House of Quality (HOQ) 1. Whereas the diagram shows the criteria expected by the customer as well as the actions that will be executed to meet customer desires. In the HOQ diagram shows the relationship between what the customer wants or Voice of Costumer (What) and how to meet the customer's wishes or Voice of Engineer (How) and determine the correlation between the two. The next process is to specify the part requirement, or in this case to develop the HOQ 2 as shown in Fig. 4

\section{CONCLUSIONS}

Jacket designed looks like rider jacket model / touring. The addition of accents on the stitches makes the jacket more stylish. The selection of dark colors will create the dashing and masculine look. In supporting the safety of the jacket, its equipped with a protective shield of the shoulder and elbow. The selection of the main material of the jacket is Taslan cloth where the material also accommodates windbreaker and waterproof features as well as to be adaptive to cold air, dacron added as the inner material of the jacket.
In the attribute of the minimization of accessories and the combination of symbols, done by combining the six symbols into one place by using the light bulb Fulbright type 5730. The merger did so that the symbol becomes large and the size of the dot matrix is proportional. The light is animatedly blinking to increase awareness in driving while viewing the symbol; the blink interval is $500 \mathrm{~ms}$.

The symbol used refers to Indonesia traffic system, to encounter the understanding of the symbol meaning. The six symbols are for turning, refueling, danger to the right or left, accelerating, decelerating, and stopping. A sample of visualization shown in Fig. 7 and Fig. 8.

In addition to several requirements specifications described on jacket design, system design, and symbols. There's also some specification of supporting components required for the manufacture of this product which assesses in the QFD process (accessories minimization, buzzer \& vibration, SMD Fulbright, NRF24L01).

The device operating system work by integrating all of the receivers by connecting all the device through radio frequency. By configuring the front driver of the group as the leader, all of the instruction commanded by the leader will be displayed on it is back and automatically to others group member as well. The illustration is shown in Fig. 5.

This study has developed safety equipment based on customer's voice by combining performance factors and design factors. The formulation of designing the product is within the QFD methods framework. The development of the prototype been conducted independently with resulting alpha prototype. The checking phase has been conducted by doing a usability test to evaluate the performance of the prototype. 


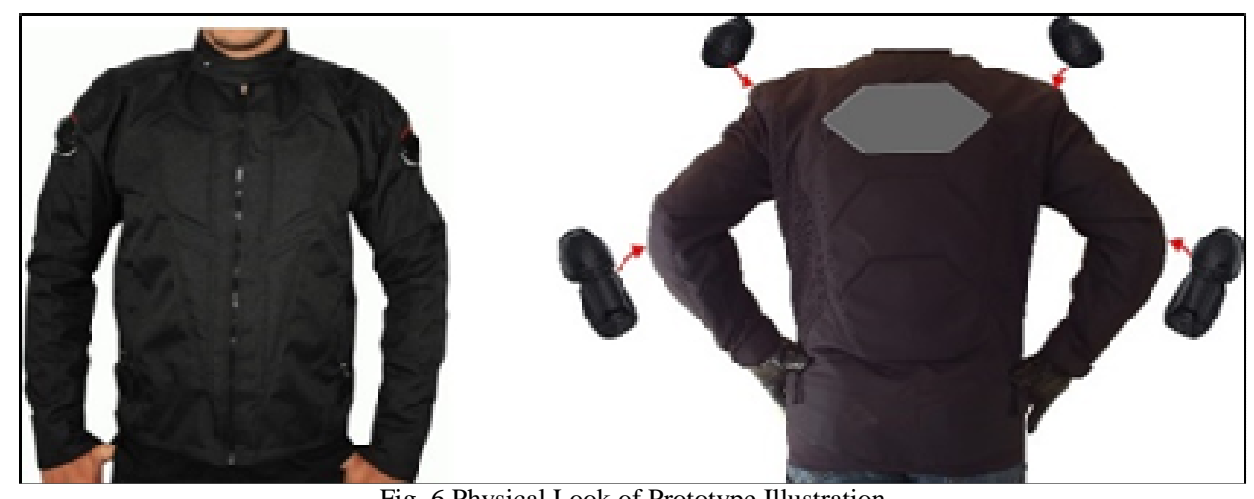

Fig. 6 Physical Look of Prototype Illustration

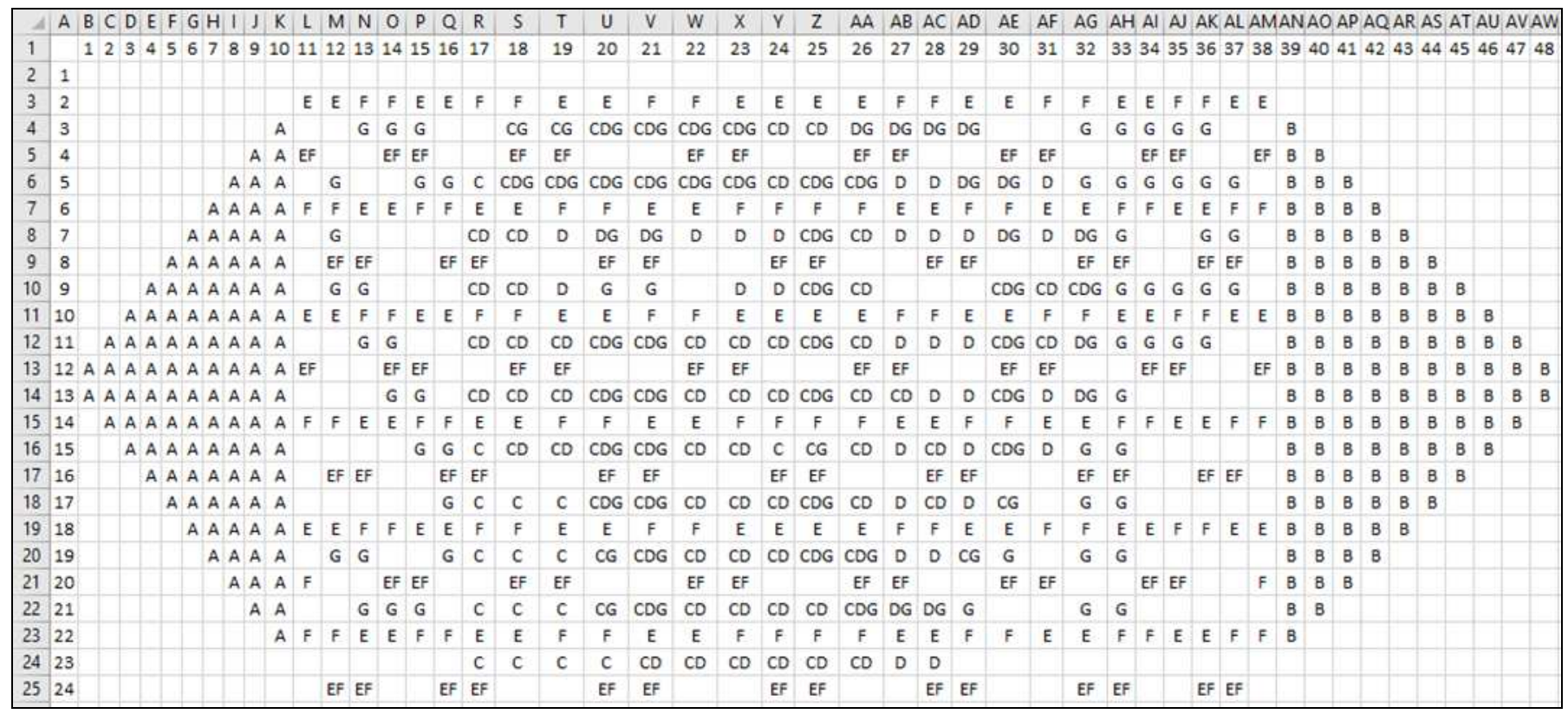

Fig. 7 Display Configuration

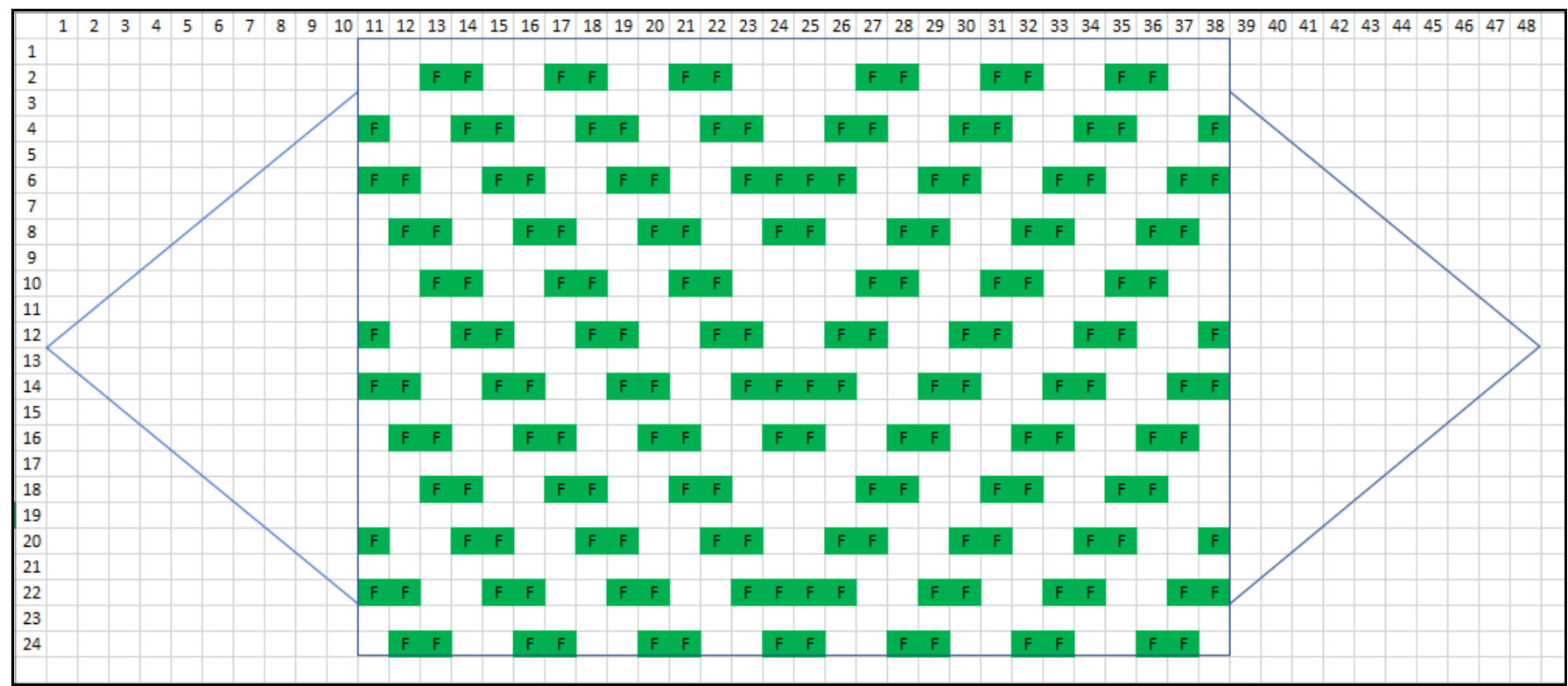

Fig. 8 Sample of Decelerating Display

2180 
Action lastly taken based on the evaluation to give an improvement to the product by doing beta prototype.Additional research needed to give more advanced features which supporting the integrated system and increasing the portability factors. For instance, by embedding GPS or buzzer in order to keep the pack's member on bond, as well the equipment is built in detachable and compact form. Another further improvement has to put as consideration in order to make the equipment come up with a higher standard and suitable with the different condition in different regions.

What another part to be considered for further improvement is to design and to engineer the product to be installed on any type of motorcycle. As the limitation found on this study was the panel of the remote button can only be installed on a specific type of motorcycle with the slimmer size of steering-bar.

For the feature that may need more further improvement is the display. The further study can develop open-system configuration. Thus it can enable the user to configure the product by their needs. So, the signals or message delivered through the display can suit the situation where the driver goes and ride.

\section{ACKNOWLEDGMENT}

First and foremost, the authors must acknowledge the gratitude to Allah, the Ever Magnificent for His help and bless. This work would have never become true, without His guidance. We also would express our thank to Kemenristekdikti (Ministry of Research, Technology and Higher Education) who gave us a chance to realize this research program through students' creativity program (PKM).

\section{REFERENCES}

[1] Burge, S. Quality Function Deployment (QFD). Systems Engineering, 2007, 1-33.

[2] Kurniawan, A. (2014). Populasi Kendaraan Bermotor di Indonesia Tembus 104,2 Juta Unit. [Internet]. Available from: http://otomotif.kompas.com/read/2014/04/15/1541211/Populasi.Kend araan.Bermotor.di.Indonesia.Tembus.104.2.Juta.Unit

[3] Williams, V., McLaughlin, S., McCall, R., \& Buche, T. Motorcyclists' self-reported riding mileage versus actual riding mileage in the following year. Journal of Safety Research, 2017, 63, 121-126.

[4] Nagamachi, M. Kansei Engineering as a Powerful Consumer Oriented Technology for Product Development. Applied Ergonomic, 2002, pp. 289-294.

[5] Norman, D. Emotional Design: Why We Love (or Hate) Everyday Things. Singapore: Prentice Hall. 2004.

[6] Restantin, N. Y., Ushada, M., \& Ainuri, M. Desain Prototipe Meja dan Kursi Pantai Portabel dengan Integrasi Pendekatan Ergonomi, Value Engineering dan Kansei Engineering. Jurnal Teknik Industri Vol. 14 No.1, 2012, 53-62.

[7] Ulrich, K. T., \& Eppinger, S. D. Product Design and Development Product Design and Development. 2012. [Internet]. Available from: https://doi.org/10.1016/B978-0-7506-8985-4.00002-4

[8] Motorcycle Operator Manual. Irvine: MSF Motorcycle Safety Foundation. 2011

[9] Pat Lancaster, R. H. Using Kaizen KAIZEN to Improve Designs and to Speed Development - How Lantech Kaizened a Problem Product. Retrieved from AME - Association for Manufacturing Excellence. 1995. [Internet]. Available from: http://www.ame.org/sites/default/files/documents/95Q5A2.pdf

[10] Paul, A. K., \& Devnath, L. An Approach to Increase Motorcycle Safety by Analyzing Some Factors of Motorcycle and Road Surface. Imperial Journal of Interdisciplinary Research, 2(9). 2016.

[11] Song, M., McLaughlin, S., \& Doerzaph, Z. An on-road evaluation of connected motorcycle crash warning interface with different motorcycle types. Transportation Research Part C: Emerging Technologies, 2017, 74, 34-50.

[12] World Health Organization Helmet Initiative (Accessed 5 November 2017, at http://www. whohelmets.org/about.htm). 